\title{
LA COERCIÓN FEDERAL EN LA LEY FUNDAMENTAL. LA RECEPCIÓN DE UNA CATEGORÍA CLÁSICA DEL SISTEMA DESCENTRALIZADO ALEMÁN
}

\author{
LEONARDO ÁLVAREZ ÁLVAREZ \\ Profesor Titular de Derecho Constitucional \\ Universidad de Oviedo
}

\section{SUMARIO}

I. El tratamiento de la coerción federal en la Ley Fundamental. Concepto y clases de coerción en el sistema descentralizado. II. El principio de unidad del sistema descentralizado como objeto de tutela del poder de coerción federal. III. Las medidas de coerción federal en garantía del principio de unidad del sistema descentralizado. IV. Los órganos intervinientes en el procedimiento de coerción federal. V. Conclusiones.

\section{EL TRATAMIENTO DE LA COERCIÓN FEDERAL EN LA LEY FUNDAMENTAL. CONCEPTO Y CLASES DE COERCIÓN EN EL SISTEMA DESCENTRALIZADO}

\section{La Bundeszwang de la Ley Fundamental y la tradición histórica de la Reichsexekution}

En España, los agentes políticos y los académicos han recurrido con frecuencia a la categoría de la coerción federal (Bundeszwang, en adelante, BZ) del art. 37,1 de la Ley Fundamental de 1949 (en adelante LF) para coadyuvar a la interpretación del art. 155 CE, acogido en el texto constitucional de 1978 por influjo de la LF. Muchos de los problemas hermenéuticos que ha presentado el art. $155 \mathrm{CE}$ han sido ya conocidos y solventados en el seno de la propia LF. Por ello, puede tener sentido dedicar un estudio a la BZ en el Estado federal alemán. Si bien ello podría sorprender, lo cierto es que la BZ apenas ha sido objeto de una construcción teórica propia, habiéndose importado sus resultados por la 
literatura principalmente de la categoría de la Reichsexekution (en adelante, $\mathrm{RE})$, de la historia del constitucionalismo alemán ${ }^{1}$.

El concepto de RE describe el modelo de coerción en el sistema descentralizado acogido en los documentos constitucionales vigentes hasta la entrada en vigor de la LF: en el art. XXI del Acta Final de Viena de 1820 —en el que se encuentran los precedentes del poder de coerción-, en el art. 19 de la Constitución de la Confederación del Norte de 1867, en el art. 19 de la Constitución Imperial de 1871 y en el art. 48,1 de la Constitución de Weimar de $1919^{2}$. Ha sido precisamente en el debate académico de la RE donde se han desarrollado los más relevantes problemas teóricos. Si algo arroja el desarrollo doctrinal de la RE es que tanto el contenido como la función de un poder de coerción reconocido en el seno del sistema descentralizado dependen, sobre todo, de dos elementos estructurales del orden jurídico: a) del concepto de Estado y de Constitución y b) del modelo de descentralización territorial ${ }^{3}$.

La paulatina evolución de estos elementos estructurales en los documentos constitucionales generaría un rico debate doctrinal que analizaría en qué medida los tradicionales mecanismos de coerción del siglo XIX podían ser compatibles con los pasos dados, entre otros aspectos, hacia una federalización del Estado ${ }^{4}$. En el estudio del vigente art. 37 LF se echan en faltan estos debates teóricos de la RE, habiendo optado la doctrina por asumir, en muchas ocasiones de forma acrítica, buena parte de las conclusiones presentadas por el desarrollo doctrinal de la RE. Es probable que a ello haya contribuido la ausencia de aplicación práctica de la BZ hasta la actualidad, algo que los académicos han atribuido, entre otros motivos, a la plena federalización de las relaciones entre el Bund y los Länder y a la aceptación de la labor práctica de la jurisdicción constitucional y contencioso-administrativa,

1 Véase H. BAuer, «Artikel 37 [Bundeszwang] en H. Dreier (edit)., Grundgesetzkommentar, vol II, ed. Mohr, Siebeck, Tübingen, 1998, marg. 1. No han existido monografías en la literatura alemana actual que se hayan dedicado al estudio de la BZ. Integran la bibliografía consolidada de los estudios existentes sobre la BZ diferentes tesis doctorales inéditas, defendidas durante los primeros años de vigencia de la LF, que no han podido ser consultadas para la elaboración de este trabajo: G. SpIEss, Der Bundeszwang, diss Heidelberg, 1954, H. HaAs, Die Bundesaufsicht und der Bundeszwang, Diss. Heidelberg, 1955, S. Nöltig, Der BundeszwangArt. 37 des Grundgesetzes, Diss. Göttingen, 1956, P. M. Mombaur, Bundeszwang und Verfassungstreue, Diss. Köln, 1964, H. D., Рӧтschske, Bundesaufsicht und der Bundeszwang nach dem Grundgesetz, Diss. Wütszburg, 1967. Por otra parte, las conclusiones presentadas por la doctrina alemana actual han permanecido inmodificadas durante la vigencia de la LF, ya desde los primeros estudios publicados al respecto. Pueden consultarse, entre otros, G. A. ZINN, Die Bund und die Länder, AöR, 75, 1949 y H. SCHäFER, Bundesaufsicht und Bundeszwang, AöR, 78, 1952/1953.

2 Por poner solo algún ejemplo, el art. 19 de la Constitución Imperial de 1871 disponía: Cuando los miembros del Bund no cumplan con sus obligaciones constitucionales pueden ser contenidos a través de la ejecución (Exekution).

3 Así lo ha puesto de manifiesto la doctrina actual, véase H. BAuer, op. cit., marg. 1.

4 Sobre todo, diferentes trabajos publicados durante la vigencia de la Constitución de 1871, véase A. Hänel, Deutsches Staatsrecht, vol. I, ed. Duncker \& Humblot, Leipzig, 1896, p. 449 y ss., M. Von SEYDEL, Commentar zur Verfassungs-Urkunde für das deutsche Reich, ed. A. Stuber's Buchhanlung, 1893, p. 137 y ss., H. TriePel, Die Reichsaufsicht. Untersuchungen zum Staatsrecht des deutschen Reiches, ed. Duncker \& Humblot, Berlin, 1917, p. 676 y ss. 
que han sido capaces de solventar relevantes conflictos territoriales ${ }^{5}$. Sin embargo, lo cierto es que el poder de coerción tampoco fue objeto de aplicación práctica durante el periodo de vigencia de la Constitución de 1871 y fue precisamente en dicho periodo histórico en el que la literatura sentó los perfiles del modelo de coerción en el sistema descentralizado, que han llegado hasta la actualidad ${ }^{6}$.

En el contexto de las consideraciones expuestas, este trabajo se ha propuesto analizar 1) cuál es el contenido que la doctrina ha atribuido a la coerción federal plasmada en el art. $37 \mathrm{LF}, 2$ ) de qué manera han influido los debates teóricos de la RE en el desarrollo de sus conclusiones y 3) qué concretos elementos autónomos se han atribuido a la BZ en el seno de la LF, que permitan diferenciarla del anterior modelo de coerción.

\section{El concepto de coerción en el sistema territorialmente descentralizado. La coerción indirecta y la coerción directa}

Tres son las notas definitorias comunes de la RE y de la BZ en el sistema descentralizado: a) el objeto de tutela, b) el elemento orgánico y c) el elemento coactivo. En lo que se refiere, en primer lugar, al objeto de tutela, la RE y la BZ se conciben como mecanismos destinados a responder, principalmente, frente a infracciones de la Constitución por parte de los sujetos descentralizados ${ }^{7}$. Es por ello que la RE y la BZ se han definido, en un sentido amplio, como institutos de defensa de la Constitución ${ }^{8}$. Una Constitución entendida —más allá de su diferente concepto asumido a lo largo del tiempo- como la norma constitutiva del sistema descentralizado. A pesar de lo expuesto, lo cierto es que la RE y la BZ no responden frente a cualesquiera vulneraciones de la Constitución, sino solo frente a aquellas que pongan en peligro la cohesión de los sujetos del sistema territorialmente descentralizado ${ }^{9}$. En concreto, el principio de unidad $^{10}$.

5 Vease H. BAuer, op. cit., marg. 6.

6 El debate académico suscitado durante la vigencia de la Constitución de 1871 se centró en determinar si el poder de coerción reconocido en el Acta Final de Viena de 1820 y, en particular, el modo en el que fue aplicado en varias ocasiones, podía ser importado a una Constitución Imperial de 1871 ante lo genérico de su dicción. Debe de reiterarse aquí lo dispuesto en su art. 19: Cuando los miembros del Bund no cumplan con sus obligaciones constitucionales pueden ser contenidos a través de la ejecución. Sobre el contexto del debate doctrinal véase P. Schilling, Die Reichsexekution, AöR, n. ${ }^{\circ}$ 20, 1906, p. 62. Por su parte, sobre la aplicación del poder de coerción durante la vigencia del Acta Final de Viena, véase E.-R. Huber, Deutsche Verfassungsgeschichte seit 1789, vol. I, ed. Kohlhammer, Stuttgart y otros, 1960, p. 634 y ss.

7 Véase respectivamente P. Schilling, op. cit., p. 62 y H. H. KLEIN, «Artikel 37 [Bundeszwang]» en T. Maunz y G. Dürig, (edits.), Grundgesetzkommentar, ed. CH. Beck, München (hojas intercambiables, 2010), marg. 2.

8 Véase E.-R. Huber, «Bundesexekution und Bundesintervention. Ein Beitrag zur Frage des Verfassungsschutzes im Deutschen Bund», AöR, 79 (1953/1954), p. 1 y 2.

9 Véase E.-R. Huber, Deutsche Verfassungsgeschichte, vol. I, op. cit., p. 635 y H. Triepel, op. cit., p. 676 y 677 .

10 Véase H. Triepel, op. cit., p. 676 y 677. 
En lo relativo, en segundo lugar, al elemento orgánico, la RE y la BZ se caracterizan por conferir la garantía del principio de unidad del sistema descentralizado a órganos del Estado central a los que se les atribuye la función ejecutiva; según los distintos periodos históricos al Kaiser, al Presidente del Reich o al Gobierno de la federación. Se trata, en ese sentido, como ha afirmado la doctrina, de una defensa ejecutiva de la Constitución ${ }^{11}$. Probablemente este haya sido uno de los rasgos más característicos de la RE y de la BZ, que han diseñado una defensa no jurisdiccional de la Constitución. De cualquier forma, debe de reconocerse, como se verá, que la posibilidad de deslindar la defensa ejecutiva de la Constitución de la jurisdiccional ha sido mayor o menor durante los diferentes periodos históricos ${ }^{12}$.

La tercera de las características comunes de la BZ y de la RE es el elemento coactivo. A ello alude directamente la expresión Bundes-zwang (coerción), pero lo engloba también, desde luego, la de Reichs-exekution, que pone su acento en la idea de ejecución o de cumplimiento. En realidad, ambas categorías expresan las dos caras de una misma moneda: el cumplimiento / coactivo de la Constitución. La cuestión se centra en definir cómo las categorías de la BZ y la RE conciben ese cumplimiento coactivo de la Constitución. La literatura ha dividido ese elemento coactivo en dos momentos: los mecanismos de coerción indirecta y los de coerción directa ${ }^{13}$. Los mecanismos de coerción indirecta abarcan un conjunto de medidas adoptadas por el Estado central que tienen como finalidad forzar (ahí reside el elemento coactivo) a los sujetos descentralizados al cumplimiento de las normas constitucionales infringidas. Entre las medidas aceptadas a lo largo de las diferentes etapas históricas: la ocupación militar del territorio, la impartición de instrucciones, el envío de comisarios y las medidas de presión financiera ${ }^{14}$.

Por su parte, los mecanismos de coerción directa, ante el desfallecimiento de los anteriores, permiten al Estado central, en contra de la voluntad de los sujetos descentralizados (elemento coactivo), proceder por sí mismo al cumplimiento de las normas constitucionales infringidas. Los mecanismos de coerción directa implican propiamente, como se ha denominado tanto en la teoría de la RE como en la de la BZ, un secuestro (sequestratio) temporal o definitivo de las competencias que la Constitución atribuye a las entidades descentralizadas, que pasan a ser ejercidas por el Estado central. En estos términos cabe hablar de una suspensión de la autonomía de aquéllos ${ }^{15}$. Entre las medidas reconducidas históricamente a

11 Véase E.-R. Huber, «Bundesexekution und Bundesintervention...», op. cit., p. 2.

12 Cfr. E.-R. Huber, Deutsche Verfassungsgeschichte seit 1789, vol. I, op. cit., p. 635, G. AnsChüTZ, «Die Reichsexekution», en G. Anschütz y R. Thoma (edits.), Handbuch des deutschen Staatsrechts, ed. Mohr, Tübingen, 1998, p. 378 y H. H. KLEIN, op. cit., marg. 57.

13 Véase A. HäNel, op. cit., p. 449 y ss.

14 Sin perjuicio de ulteriores consideraciones, véase F. SHIRVANI, «Der Bundes und Reichsexekution in der neuehen deutschen Verfassungsgeschichte», Der Staat, 50, 2011, p. 110 y ss.

15 Véase respectivamente H. TriePel, op. cit., p. 672 y ss. y H. H. KleIN, op. cit., marg. 86. 
este modelo de coerción: la guerra, la posibilidad de derogar normas constitucionales, la de aprobar y derogar leyes, reglamentos y actos administrativos, el cese del jefe del gobierno y de sus ministros y su sustitución por comisarios designados por el Estado central, la disolución de los parlamentos de las entidades descentralizadas... ${ }^{16}$.

\section{EL PRINCIPIO DE UNIDAD DEL SISTEMA DESCENTRALIZADO COMO OBJETO DE TUTELA DEL PODER DE COERCIÓN FEDERAL}

1. La regulación del supuesto de hecho del poder de coerción del art. 37,1 LF en el contexto del constitucionalismo histórico.

El art. 37,1 LF, en la redacción del supuesto de hecho del poder de coerción federal, ha seguido la tradición de la RE en los textos constitucionales, que la concibieron principalmente, como se acaba de ver, como un mecanismo destinado a responder frente a las infracciones de la Constitución. Los arts. 19 de la Constitución de la Confederación del Norte de 1867 y de la Constitución Imperial de 1871, erigieron como supuesto de hecho del poder de coerción que alguno de sus miembros «no cumpla (n) con las obligaciones federales impuestas conforme a la Constitución». A esto mismo ha aludido la primera parte del art. 37,1 LF, al afirmar que procede la aplicación de la coerción federal cuando «un Land no cumpliere las obligaciones federales que la Ley Fundamental... le imponga(n)».

Sin embargo, a primera vista, la configuración del supuesto de hecho del poder de coerción del art. 37,1 LF se inspira más directamente en lo dispuesto en el art. 48,1 de la Constitución de Weimar de 1919, a pesar de que en éste no se aludiera al incumplimiento de obligaciones federales —como había sucedido en las Constituciones de 1867 y 1871 — sino que se refiriera, más genéricamente, a la infracción de obligaciones ${ }^{17}$. El art. 37,1 LF, como la Constitución de Weimar, establece como supuesto de hecho para la aplicación de la coerción federal no solo el incumplimiento de las obligaciones federales previstas en la Constitución, sino que introduce en aquel supuesto también a la ley, como fuente de obligaciones. En su total regulación del supuesto de hecho, el art. 37,1 LF dispone: «cuando un Land no cumpliere con las obligaciones federales que la Ley Fundamental y otras leyes federales le impongan».

16 Véase de nuevo F. Shirvani, op. cit., p. 110 y ss.

17 De cualquier forma, esta distinción fue más aparente que real, ya que, como se verá, el debate académico ha entendido que las obligaciones a las que alude el art. 48,1 del texto constitucional de 1919 se refieren a las obligaciones federales vinculadas con el principio de unidad, véase G. ANSCHÜTZ, op. cit., p. 378. 
De cuanto se acaba de exponer, pareciera deducirse que en la historia del constitucionalismo alemán, el supuesto del poder de coerción presenta dos modelos; los textos constitucionales que erigen a la Constitución como fuente de obligaciones federales y los documentos que, además, incluyen a las leyes del Estado central. Sin embargo, lo cierto es que estos dos modelos han acabado por diluirse en el debate académico. Ya durante la vigencia de la Constitución de 1871, la literatura interpretó que la cláusula «obligaciones federales impuestas conforme a con la Constitución» incluía, además de las plasmadas en el texto constitucional, las previstas en las leyes aprobadas conforme a la Constitución ${ }^{18}$. En realidad, puede afirmarse que las categorías de la RE y de la BZ se identifican en este punto.

\section{El concepto de obligación federal y el principio de unidad del Estado federal. El concepto de Constitución y la estructura del sistema descentralizado}

La función del poder de coerción previsto en el art. 37,1 LF se ha construido en la literatura a partir del concepto obligaciones federales (plasmadas en la Constitución y en las leyes del Estado central). El concepto obligaciones federales se ha delimitado a partir del principio federal del art. 20,1 $\mathrm{LF}^{19}$. De acuerdo con esta premisa, el debate académico ha concluido que las obligaciones federales a las que se refiere el art. 37,1 LF son las que vinculan a los diferentes Estados federados como miembros de dicha unidad ${ }^{20}$. Por ello cabe afirmar que el poder de coerción federal no responde frente a cualquier infracción normativa procedente de aquellos sujetos, sino tan solo frente a las que pongan en peligro el funcionamiento unitario del Estado federal ${ }^{21}$.

Esta relación entre el poder de coerción y el principio de unidad del sistema territorialmente descentralizado fue, en realidad, ya apuntada desde la teoría de la RE. A pesar de que el art. 48,1 de la Constitución de 1919, tal como se ha señalado, aludiera a que el poder de coerción respondía frente a un incumplimiento de las obligaciones por parte de los Länder — sin alusión al adjetivo federales-, el debate académico acabó reconduciéndolas a las relacionadas con el principio de unidad del sistema descentralizado ${ }^{22}$. Lo cierto es que durante la

18 Véase P. Schilling, op. cit., p. 62. También A. HäNEL, op. cit., p. 446.

19 Véase, entre otros, T. Maunz, op. cit., marg. 31.

20 Véase H. H. Klein, op. cit., 24, W. ErbGuth, «Art. 37» en M. SACHS (edit.), Grundgesetzkommentar, ed. CH. Beck, München, 2009, marg. 8, M. Gubelt, op. cit., marg. 5, G. A. ZINN, op. cit., p. 304.

21 Véase T. Maunz, op. cit., marg. 31.

22 Y ello al margen de las eventuales dificultades que tanto el concepto de Constitución como la estructura del ordenamiento generaron para la adecuada construcción de dicha unidad normativa. Véase G. ANSCHÜTZ, op. cit., p. 378. 
vigencia de la Constitución de 1919 la literatura ya negó que la infracción de cualquier obligación constitucional o legal por los Länder pudiera acarrear el ejercicio del poder de coerción por parte del Presidente del Reich.

En una construcción gestada en el debate académico de Weimar, se excluyeron del concepto obligaciones al que aludía el art. 48,1 de la Constitución, en concreto, las relaciones jurídicas de derecho privado o incluso algunas vinculadas al derecho público, como las urbanísticas, las financieras y las de policía, en tanto su infracción no era idónea para afectar al principio de unidad del sistema descentralizado ${ }^{23}$. Estas conclusiones han sido plenamente asumidas por la doctrina en la interpretación del concepto obligaciones federales previsto en el art. $37 \mathrm{LF}^{24}$.

Esta relación entre el poder coerción y el principio de unidad del sistema descentralizado no pudo construirse coherentemente durante el siglo XIX. Y ello a pesar de que Constituciones, como la de 1871, al igual que sucede con la vigente LF, concibieron expresamente el poder de coerción como una respuesta frente a la infracción de las obligaciones federales por parte de los miembros del Bund. Aunque incluso entonces fue posible identificar posiciones en el debate académico que intentaron vincular las obligaciones federales, no con la totalidad de las normas constitucionales, sino con una denominada Constitución en sentido material —eventualmente expresiva de una unidad $2^{25}$, los elementos estructurales sobre los que se edificó el sistema territorialmente descentralizado impedirían la adecuada construcción de una unidad jurídica superior a sus miembros.

La naturaleza confederal del Reich — que suscitó, sin embargo, una importante controversia doctrinal $-{ }^{26}$, que cristalizaría en una concepción pactista de Constitución ${ }^{27}$, condujo a una así definida por la literatura «identificación entre el Estado total y el Estado central ${ }^{28}$. El objeto de protección del poder de coerción durante el siglo XIX no fue, en consecuencia, el funcionamiento unitario del sistema descentralizado, sino más bien los intereses del Reich, cuya posición de superioridad sobre los Bundestaate, le permitía construir y definir por sí mismo el contenido de dicha unidad ${ }^{29}$. Fue esta naturaleza del Estado y de la Constitución, y su incidencia sobre el modelo de descentralización, la que justificó que se admitiera como principal mecanismo de RE — conviene ya adelantarlo- la

23 Véase G. ANschüTz, op. cit., p. 378.

24 Véase T. Maunz, op. cit., marg. 16, H. H. KLein, op. cit., marg. 45.

25 Véase E.-R. Huber, Deutsche Verfassungsgeschichte seit 1789, vol III, ed. Kohlhammer, Stuttgart y otros, 1988, p. 1034.

26 A favor de la naturaleza confederal del Reich véase M. VON SEYDL, op. cit., XVI. Crítico al respecto P. LABAND, Das Staatsrecht des deutschen Reiches, vol. I, ed. JCB Mohr, Berlin/Leipzig, 1895, p. 80 y ss.

27 Véase R. SMEND, «Ungeschriebenes Verfassungsrecht im Monarchischen Bundesstaat» en idem., Staatsrechtlichen Abhandlungen, ed. Duncker \& Humblot, Berlín, 1968, pp. 56 y 57.

28 Véase E.-R. Huber, Deutsche Verfassungsgeschichte, vol. III, op. cit., p. 792.

29 Véase, entre otros, P. LABAND, op. cit., p. 93 y ss. 
guerra, un instituto coactivo del derecho internacional, al amparo del cual se construyó el modelo de descentralización de la confederación ${ }^{30}$.

A pesar de lo expuesto, el análisis doctrinal del vigente art. 37,1 LF no se ha hecho eco de la teorización desarrollada en el debate académico de la Constitución de Weimar de 1919, que acometió el estudio del poder de coerción a la luz de la «teoría de los tres miembros del Estado federal», cuando ya fue posible construir propiamente un principio de unidad en el seno del sistema territorialmente descentralizado. Esta construcción doctrinal no concibió el poder coerción como un mecanismo al servicio de la protección de los intereses del «Estado central», como había sucedido en el siglo XIX, sino más bien del «Estado total» ${ }^{31}$. A pesar de que algún autor, en el estudio del vigente art. 37,1 LF, haya llegado a afirmar que el poder de coerción responde frente a infracciones de los Länder dirigidas al «Estado total» ${ }^{32}$, lo cierto es que el TCF y la mayoría de la doctrina han descartado la teoría de los tres miembros del Estado federal para acometer el estudio del poder de coerción. Sin embargo, los vestigios de esta construcción, como se verá, pueden identificarse implícitamente en el debate académico de la BZ.

\section{La plasmación de las obligaciones federales en la Constitución o en otras leyes federales}

El art. 37,1 LF precisa, como supuesto del poder de coerción, que las obligaciones federales han de estar plasmadas en la «Constitución o en otras leyes federales». En lo que se refiere, en primer lugar, a la definición de las normas constitucionales en las que pueden identificarse las obligaciones federales, la doctrina ha llevado a cabo, fundamentalmente, una argumentación excluyente. Siguiendo, recuérdese, los resultados ya expuestos por la teoría de la RE durante

30 Véase H. Kelsen, «Die Bundesexekution. Ein Beitrag zur Theorie und Praxis des Bundestaates, unter besonderer Berücksichtigung der deutschen Reichs- und der österreichischen Bundes-Verfassung» en Z. Giacometti y D. Schindler (edits.), Festgabe für Fritz Fleiner zum 60 Geburtstag, JCB Mohr, Siebeck, 1927, p. 162 y ss. En la doctrina de la época véase J. JellineK, System der subjetiven öffentlichen Rechte, JCB Mohr, Freiburg, 1892, p. 295 y 296, G. MEYER, Lehrbuch des deutschen Staatsrechtes, ed. Duncker \& Humblot, Leipzig, 1891, p. 644, L. Von RöNnE, Das Staats-Recht des Deutschen Reiches I, ed. Brockhaus, Leipzig, 1876, p. 72, M. Von SEYDL, op. cit., p. 137 y ss. Sin embargo, hay que reconocer que ya por entonces, como se verá más adelante, algunas posiciones reconocieron que, además la ocupación militar del territorio, podían emplearse otros mecanismos de sustitución, como la disolución de las asambleas legislativas de los Bundestaate, la aprobación de leyes, de actos de gobierno, la deposición de autoridades, el envío de comisarios, véase H. Triepel, op. cit., p. 680 y ss., R. Von MoHL, Das deutsche Reichsstaatsrecht. Rechtliche und politische Eröterungen, ed. Laupp'schen Buchhandlung, Tübingen, 1893, p. 159 y 160, A. HëNEL, op. cit., p. 450 y ss., P. SCHILLING, op. cit., p. 72, 75. Este tipo de medidas sustitutivas de la RE fueron ya pacíficamente asumidas en el contexto de la Constitución de Weimar de 1919, véase G. ANschüTz, op. cit., p. 379.

31 Véase H. Kelsen, op. cit., p. 166 y 167.

32 Véase H. BAuER, op. cit., marg. 5. El citado autor apoya su construcción en la BVerfGE 13, 54 que afirmó: «El Bund y los Länder poseen la obligación colectiva de defender y construir el orden constitucional fundamental en todas las partes y planos del Estado total». 
la vigencia de la Constitución de $1919^{33}$, se ha excluido como fuente de obligaciones federales a las normas constitucionales que imponen relaciones de derecho privado o de derecho público, como las urbanísticas, financieras o de policía, en tanto no vinculan inmediatamente a sus miembros con el principio federal del art. 20,1 $\mathrm{LF}^{34}$. De todos modos, algún sector doctrinal, apoyándose en cierta jurisprudencia del TCF ${ }^{35}$, se ha mostrado crítico en lo relativo a la posibilidad de excluir las normas financieras para definir el concepto de obligaciones federales del art. $37,1 \mathrm{LF}^{36}$.

Otras posiciones, sin embargo, en el seno de la vigente LF han abandonado este modelo de argumentación excluyente mayoritariamente seguido en el debate académico para definir el concepto de obligaciones federales y han intentado precisar las normas constitucionales en las que podría identificarse el principio de unidad del Estado federal y, por tanto, el supuesto de hecho del poder de coerción. «Entre ellas», así se ha afirmado, las que se refieren a los principios fundamentales que han de garantizar las Constituciones de los Estados (28,1 LF), las relativas a la ayuda recíproca en caso de peligro contra la seguridad y el orden público y en supuesto de catástrofe (art. 35 LF), a la designación de senadores (art. 51), a la ejecución de las leyes federales por parte de los Estados (arts. 84 y 85 LF) o la distribución de gastos entre los Estados y la federación (art. 104 a) LF) ${ }^{37}$.

Un mayor debate académico se ha suscitado en torno a la interpretación de la cláusula otras leyes federales que, junto con la propia LF, pueden ser fuente de obligaciones federales, según lo previsto en el art. 37,1 LF. En este punto, la literatura se ha dividido entre un concepto formal y material de ley, que también ha estado presente en la teoría de la $\mathrm{RE}^{38}$. Mientras la primera de las posiciones entiende que solo la forma ley podría ser fuente de las obligaciones federales ${ }^{39}$, la segunda identifica el concepto leyes federales con derecho escrito, pudiendo identificarse el supuesto de hecho del poder de coerción, según las distintas posiciones, en las leyes y en los reglamentos de la Federación ${ }^{40}$, en los tratados internacionales e incluso en el derecho comunitario ${ }^{41}$. A pesar de esta disparidad doctrinal, ha existido consenso a la hora de negar como fuente de obligaciones federales del art. 37,1 LF al derecho consuetudinario, al derecho constitucional no escrito, a las resoluciones, a las instrucciones, a las recomendaciones del

33 Véase G. AnschüTz, op. cit., p. 378.

34 Véase H. H. KLein, op. cit., marg. 45, M. Gubelt, «Art. 37 (Bundeszwang) en I. Von MünCH (edit.), Grundgesetz-Kommentar, ed. CH. Beck, München, 1976, marg. 5, T. Maunz, op. cit., marg. 16.

35 BVerfGEE. 3, 52, 32, 199.

36 Véase W. Pauly/C. PaGel, Bundeszwang in der föderalen Finanzordnung, DÖV, 2004.

37 Véase H. Bauer, op. cit., marg. 85.

38 Véase P. Schilling, op. cit., p. 62, A. HäNEL, op. cit., p. 446.

39 Véase H. BAuer, op. cit., marg. 10, W. ErbGuth, op. cit., marg. 8 y M. Gubelt, op. cit., marg. 6.

40 Véase R. Sannwald, «Art. 37» en B. Schmidt-Bleibtreu y F. Klein (edits.), GG: Kommentar zum Grundgesetz, ed. Carl Heymanns, Köln, 2014, marg. 7, H. H. Klein, op. cit., marg. 49.

41 Véase H. H. Klein, op. cit., marg. 85. 
gobierno o del Bundestag o a los acuerdos suscritos entre los Estados federados entre sí y entre éstos y la Federación ${ }^{42}$.

Alguna consideración en la doctrina ha merecido la cuestión de si el incumplimiento de las decisiones del TCF por los Estados puede legitimar el ejercicio del poder de coerción del art. 37,1 LF. En particular, si las resoluciones del TCF pueden ser también fuente de obligaciones federales. Quienes han abordado esta cuestión, han entendido que las resoluciones del TCF no imponen de forma autónoma ninguna obligación federal en los términos del art. 37,1 LF, sino que se limitan a «declarar» jurisdiccionalmente la infracción de las previstas en la $\mathrm{LF}^{43}$. Por el contario, se ha reconocido que las sentencias ejecutivas que imponen una obligación federal autónoma sí podrían legitimar el uso de la coerción ${ }^{44}$.

\section{El concepto de obligaciones federales y el principio de lealtad federal}

Otro de los elementos identificativos de la construcción teórica de la coerción federal en la LF ha sido su indisoluble relación con el principio de lealtad federal. La lealtad federal se ha considerado tradicionalmente en el sistema descentralizado alemán como un principio de derecho constitucional no escrito fuente de obligaciones y de prohibiciones que se dirigen a los miembros del sistema descentralizado a fin de reforzar la unidad de la que forman parte. Ha habido acuerdo en la doctrina en considerar al principio de lealtad federal como fuente de obligaciones federales en los términos dispuestos en el art. 37,1 $\mathrm{LF}^{45}$. Lo cierto es que esta conclusión ya fue generalmente admitida durante la vigencia del Acta Final de Viena de $1820^{46}$, de la Constitución Imperial de $1871^{47}$ y también de la Constitución de Weimar de $1919^{48}$. Particularmente, se ha señalado que el poder de coerción responde frente actividades desleales con la unidad del sistema, como la rebelión o la secesión ${ }^{49}$.

A pesar de que la relación entre el poder de coerción y el principio de lealtad federal ha sido una característica común a las categorías de la RE y de la BZ, ha sido, sin embargo, durante la vigencia de la LF donde la lealtad ha recibido un más detenido tratamiento, constituyendo una de sus características diferenciales. Probablemente por ello, el debate académico se ha detenido en el estudio de un particular problema, en el que no ha incidido lo suficiente la teoría de la RE. A pesar

42 Véase T. Maunz, op. cit., marg. 18 y 20, H. H. Klein, op. cit., marg. 49, R. SAnnwald, op. cit., marg. 7, M. Gubelt, op. cit., marg. 5, W. ErbGuth, op. cit., marg. 8, H. Bauer, op. cit., marg. 9.

43 Véase T. Maunz, op. cit., marg. 18, H. H. Klein, op. cit., marg. 50, K. STern, op. cit., p. 715.

44 Véase H. Bauer, op. cit., marg. 10.

45 Véase W. ERbGuth, op. cit., marg. 8, K. Stern, op. cit., I, p. 715.

46 Véase E.-R. Huber, Deutsche Verfassungsgeschichte, vol. I, op. cit., p. 635.

47 Véase H. Triepel, op. cit., p. 676.

48 Véase G. AnschüTz, op. cit., p. 378.

49 Véase H. Triepel, op.cit., p. 677. 
de que la doctrina actual ha admitido que las obligaciones federales a las que se refiere el art. 37,1 LF no tienen por qué encontrarse expresamente plasmadas en la LF o en las leyes federales, «sino que pueden ser deducidas a través de la interpretación» ${ }^{50}$ —argumento ya utilizado en la teoría de la RE para interpretar el supuesto del poder de coerción- ${ }^{51}$, ha suscitado algún problema que el principio de lealtad federal pueda convertirse verdaderamente en fuente de obligaciones federales $^{52}$. Ello se debe a que, como se ha visto, se haya excluido mayoritariamente al derecho consuetudinario y al derecho constitucional no escrito como criterios para poder definir tales obligaciones ${ }^{53}$; una naturaleza que, sin embargo, se le ha llegado a atribuir a la lealtad federal en el debate académico ${ }^{54}$.

Las dificultades expuestas han llevado a la doctrina a admitir en el supuesto de hecho del poder de coerción del art. 37,1 LF un principio de lealtad federal dotado solo de naturaleza accesoria ${ }^{55}$. Esto es, un principio no destinado a crear nuevas obligaciones federales entre los sujetos del Estado federal. Se trataría más bien de un principio llamado a reinterpretar las obligaciones federales ya previstas en la LF o en otras leyes federales en un sentido favorable a la eficacia del principio federal ${ }^{56}$. Una concepción del principio de lealtad que ha venido a manejar el propio TCF en la BVerfGE. 13, 54: «El principio de lealtad federal...constituye o limita derechos y obligaciones dentro de una relación jurídica preexistente entre el Bund y los Länder... no fundamenta autónomamente ninguna relación jurídica entre ellos».

\section{Los sujetos, los órganos y las conductas infractoras de las obligaciones federales}

La delimitación del concepto de obligación federal a partir del principio federal en el art. 37,1 LF ha servido en la doctrina para definir a) los sujetos relacionados por las obligaciones federales, b) los órganos de los Estados y c) las conductas susceptibles de infringirlas. En lo relativo, en primer lugar, a los sujetos relacionados por las obligaciones federales, si como ha señalado el propio TCF, los miembros del sistema descentralizado reconducidos a la unidad por el principio federal son la Federación y los diferentes Estados, se consideran fundamentalmente obligaciones federales en los términos del art. 37,1 LF las que relacionan,

50 Véase M. Gubelt, op. cit., marg. 6.

51 Véase A. Hänel, op. cit., p. 446, G. AnschüTz, op. cit., p. 378.

52 Véase H. BAUER, op. cit., marg. 9.

53 Véase H. H. KLein, op. cit., marg. 49 y R. SAnnwald, op.cit., p. 7.

54 Véase sobre la naturaleza del principio de lealtad federal H. BAUER, Die Bundestreue. Zugleich ein Beitrag zur Dogmatik des Bundestaatsrechts und zur Rechstverbältnislehre, ed. JCB Mohr, Tübingen, 1992, p. 4 y 5.

55 Véase H. H. KLEIN, op. cit., marg. 49.

56 Véase H. Bauer, Die Bundestreue, op. cit., p. 175 y ss. 
entre sí, a dichos sujetos ${ }^{57}$. Por tanto, queda comprendida en el supuesto de hecho del poder de coerción del art. 37,1 LF la infracción de las obligaciones debidas por los Länder frente a la Federación como frente a otros Länder. La doctrina ha excluido mayoritariamente que puedan quedar comprendidas en el concepto de obligaciones federales las debidas por los Länder frente a sus ciudadanos y frente a Estados extranjeros ${ }^{58}$.

En segundo lugar, la comentada delimitación del concepto de obligación federal a partir del principio federal ha traído como consecuencia la identificación de los órganos de los Estados de los que puede proceder la infracción de las obligaciones federales como supuesto de hecho del poder de coerción. Como se ha mantenido en la doctrina, el incumplimiento al que se refiere el art. 37,1 LF ha de proceder de los órganos superiores de los Estados, ya que son las conductas de estos órganos las que presentan mayor idoneidad para poner en peligro el funcionamiento del principio federal, objeto de tutela del art. 37,1 LF. De cualquier forma, se ha dejado unánimemente fuera de los órganos de los Estados susceptibles de legitimar el ejercicio del poder de coerción a los órganos judiciales ${ }^{59}$, siguiendo también las conclusiones del debate académico de la $\mathrm{RE}^{60}$. La independencia judicial, entonces y ahora, se presenta como el argumento para defender tal resultado. En consecuencia, hay que afirmar que los gobiernos y los parlamentos de los Estados se erigen en los órganos susceptibles de incumplir las obligaciones federales a las que se refiere el art. 37,1 LF.

El debate doctrinal ha descartado, siguiendo también las conclusiones presentadas por la teoría de la RE, que las conductas de los sujetos individualmente considerados que integran los gobiernos territoriales o sus autoridades subordinadas (ministros o secretarios de Estado), o los miembros de los Parlamentos de los Länder puedan infringir las obligaciones federales y, en consecuencia, legitimen el ejercicio del poder de coerción. Tampoco las conductas procedentes de otras personas jurídico-públicas, como los municipios y los distritos. También quedan fuera de los sujetos que pueden desencadenar el ejercicio del poder de coerción del art. 37,1 LF los ciudadanos. Frente a ellos puede ser admisible la

57 Vease W. Erbguth, op. cit., marg. 8, R. SAnnwald, op. cit., marg. 8, M. Gubelt, op. cit., marg. 5, H. BAUER, «Artikel 37», op. cit., marg. 9.

58 Véase H. H Klein, op. cit., marg. 45, T. Maunz, op. cit., marg. 19, W. ErbGuTh, op. cit., marg. 8, H. BAuer, «Artikel 37», op. cit., marg. 9, M. Gubelt, op. cit., marg. 5. Por el el contrario, en la teoría de la RE se ha admitido que las obligaciones debidas frente a Estados extranjeros quedan amparadas en el concepto de obligaciones federales, véase P. Schilling, op. cit., p. 59. Ha existido un parecer mayoritario en la teoría de la RE de que, como en la vigente de la LF, las obligaciones debidas frente a los ciudadanos no pueden legitimar el ejercicio del poder de coerción. Sin embargo, en este concreto aspecto, ha habido posiciones que han entendido que las conductas de los ciudadanos también son susceptibles de incumplir dichas obligaciones, admitiéndose que la coerción pueda ejercerse directamente contra ellos. Véase al respecto L. VON RöNNE, op. cit., p. 70 y R. VON MOHL, op. cit., p. 159.

59 Véase H. H. Klein, op. cit., marg. 41, W. ErbGuth, op. cit., marg. 7, M. Gubelt, op. cit., marg.

3, H. BAUER, «Artikel 37», op. cit., marg. 8.

60 Véase H. Triepel, op. cit., p. 499. 
aplicación de otro tipo de medidas, como las previstas en la legislación penal, aunque no el ejercicio del poder de coerción ${ }^{61}$.

La tercera de las consecuencias que se han derivado del concepto obligaciones federales del art. 37,1 LF atañe a las conductas de los Gobiernos y los Parlamentos susceptibles de generar su infracción. Existe acuerdo en la doctrina en señalar que la infracción de las obligaciones federales puede producirse por a) acciones u omisiones $^{62}$, b) incumplimientos totales o parciales, c) generados por dolo o culpa, e incluso por un incumplimiento erróneo ${ }^{63}$. En cualquier caso, el incumplimiento al que se refiere al art. 37,1 LF ha de ser efectivo, no pudiendo legitimar el ejercicio del poder de coerción la simple amenaza de que infracción pueda llegar a producirse ${ }^{64}$. Queda claro que el art. 37,1 LF, en el instrumentario de defensa de la Constitución, presenta una función represiva, no preventiva.

Si bien la definición del concepto «acciones» se ha circunscrito en la doctrina a las conductas procedentes directamente de los gobiernos y de los parlamentos de los Estados federados, la del término «omisiones» ha permitido que el ejercicio del poder de coerción pueda tener su origen en conductas de distintos órganos. Y es que, bajo el concepto omisiones, en el discurso de la coerción, se ha amparado una suerte de deber de vigilancia por parte del gobierno y de los parlamentos de los Estados como primeros vinculados, ya se ha visto, por las obligaciones federales a las que se refiere el art. 37,1 LF. Lo cierto es que en la BZ-como en la $\mathrm{RE}$ — se ha reconocido que pueden generar el ejercicio del poder de coerción las conductas de los ministros ${ }^{65}$ o de los municipios y distritos, que no hayan sido debidamente corregidas o derogadas por los Gobiernos o los Parlamentos de los Estados $^{66}$, aunque siempre en el marco de sus propias competencias. Adoptada la diligencia debida en el ejercicio de este deber de corrección, así se ha apuntado, no cabría el ejercicio de la coerción ${ }^{67}$.

Incluso se han apuntado similares resultados respecto de una obligación federal incumplida por el poder judicial de los Estados. Cuando una decisión judicial contravenga la LF u otras leyes federales y el Estado federado haya renunciado, a través de su potestad legislativa o incluso reglamentaria, a evitar en el futuro tal infracción, puede legitimarse el ejercicio del poder de coerción ${ }^{68}$. Como se puede apreciar, el concepto de imputación desempeña aquí un importante

61 Véase sobre estas cuestiones H. H. KLEIN, op. cit., marg. 42, W. ErbGUTH, op. cit., marg. 7, H. Bauer, «Artikel 37».op. cit., marg. 8, M. Gubelt, op. cit., marg. 3.

62 Véase W. Erbguth, op. cit., marg. 7, H. BAuer, «Artikel 37», op. cit., marg. 9.

63 Véase M. Gubelt, op. cit., marg. 7.

64 Véase T. Maunz, op. cit., marg. 12, K. STERn, op. cit., p. 715.

65 Véase M. Gubelt, op. cit., p. 4.

66 Véase W. Erbguth, op. cit., marg. 7, M. Gubelt, op. cit., p. 3, H. Bauer, «Artikel 37», op. cit., marg. 8. Dicho deber general de inspección de los Länder sobre el resto de entidades territoriales ha sido señalada por la BVerfGE 8, 122 (137 ss.).

67 Véase H. H. KLEIN, op. cit., marg. 43.

68 Véase H. H. KLEIN, op. cit., marg. 41. 
papel en el supuesto de hecho del art. 37,1 LF. Lo relevante es que la infracción de la Constitución o de otras leyes federales sea imputable a los gobiernos y a los parlamentos de los Estados, aunque aquella infracción no traiga causa directamente en una conducta emanada de ellos.

\section{El poder de coerción y el TCF. La constatación del incumplimiento de las obligaciones federales del art. 37,1 LF}

Probablemente una de las cuestiones más relevantes que ha planteado el reconocimiento del poder de coerción en el seno del sistema descentralizado es cuál es la relación con la función que se atribuye a los órganos jurisdiccionales para enjuiciar las conductas de sus miembros contrarias a la Constitución. Este ha sido un tema central tanto en el desarrollo de la teoría de la RE y como en la de la BZ. La cuestión tiene pleno sentido si se tiene en cuenta que el poder de coerción confiere al órgano llamado a ejercerla un juicio de naturaleza jurídica sobre el incumplimiento de la Constitución (aunque también de la ley), lo que la hace a esta función a priori coincidente con la que se atribuye a los tribunales de justicia.

Aunque hasta el momento el TCF no ha tenido la ocasión de pronunciarse con detenimiento sobre el contenido del supuesto de hecho ni sobre las medidas que podría abarcar el ejercicio del poder de coerción — como resultado de la inaplicación práctica del art. 37,1 LF-, sí ha llegado a definir cuál es el modelo de relacionarse el poder de coerción y la función del TCF. En efecto, el TCF ha concebido la coerción como un poder alternativo, no subsidiario, a su función jurisdiccional. Cosa distinta es que el ejercicio de la coerción pueda ser sometido al control posterior del TCF por la vía del art. 93, I,3 LF, algo que se ha aceptado sin discusión en la doctrina ${ }^{69}$. Como ya había anticipado en su Sentencia Weibnachtsgeld, de 10 de diciembre de 1953, el TCF reconoció en la Sentencia 7, 367 —Volksbefragung-, de 27 de mayo de 1958: «...si el Gobierno de la Federación, en particular, para el mantenimiento del orden constitucional desea ejercer el poder de coerción (art. 37,1) o provocar una decisión del Tribunal Constitucional en los términos del art. 93,1.2 LF, se somete a su decisión discrecional, no controlable por el Tribunal Constitucional».

Este modelo de relacionarse el poder de coerción y la función de los tribunales de justicia no ha sido siempre asumido en la teoría de la RE. El constitucionalismo del siglo XIX obedece, desde luego, al modelo planteado por el TCF. Durante el periodo de la confederación, se ha reconocido una, así denominada, ejecución independiente, que permitía el ejercicio de ese poder desvinculado de una previa decisión jurisdiccional. Sin embargo, el fundamento de este modelo de

69 Véase W. ERbGuTh, op. cit., marg. 5. 
ejecución independiente durante la confederación hay que encontrarlo en las carencias de la justicia constitucional. A ella se atribuía la resolución de las controversias suscitadas en el interior de los Estados miembros y las generadas entre los diferentes Estados, pero no de los conflictos existentes entre los Länder y el Bund $^{70}$, cuyos intereses, recuérdese, eran objeto de tutela por el poder de coerción, como consecuencia de la identificación entre el Estado total y el Estado central ${ }^{71}$.

El reconocimiento del poder de coerción al servicio de la garantía de la Constitución y de la unidad del sistema descentralizado tenía sentido para actuar allí donde la función judicial no podía llegar ${ }^{72}$. Algunos autores, sin embargo, durante la vigencia de la Constitución de 1871, consideraron al Bundesrath, como órgano competente para decidir sobre los conflictos entre Länder y el Reich (art. 75) y sobre la aplicación de la coerción (art. 19), no sin debates al respecto, como el supremo órgano jurisdiccional del Reich ${ }^{73}$. Sin embargo, la continuidad de este modelo de ejecución independiente — compatible con el que afirmó el TCF en el seno de la actual LF — fue ya puesto en tela de juicio por el debate académico durante la vigencia de la Constitución de Weimar de 1919. Y ello sobre la base de lo dispuesto en su art. 19, que atribuía al Staatsgerichtshof la competencia para resolver, entre otras, las competencias que se suscitaran entre los Länder y el Reich.

En el debate académico se suscitó, entonces, la cuestión de si el poder de coerción atribuido al Presidente del Reich en el art. 48,1 LF podía seguir respondiendo al modelo de ejecución independiente propio de la confederación. Desde algunas posiciones se trató de encontrar un espacio autónomo al ejercicio de la coerción, si bien ampliamente limitado por la labor del Staatsgerichtshof, ahora competente para resolver las contradicciones de la Constitución por parte de los Länder, que definía el supuesto de hecho del poder de coerción del art. 48,1. Y así, se afirmó que: «la constatación de si, en el caso concreto, se satisface el supuesto de la Reichsexekution (...) corresponde al Presidente del Reich, en tanto tal constatación no sea atribuida mediante una disposición de la Constitución o de una ley del Reich a otra instancia-por ejemplo, al Gobierno como órgano inspector (art. 15)..., al Staatsgerichtshof en el caso de conflictos entre el Reich y los Länder (art. 19)» ${ }^{74}$.

Otras posiciones, por el contrario, negaron que el poder de coerción del art. 48,1 LF pudiera responder a un modelo de ejecución independiente, y lo subordinaron a la previa actuación del Staatsgerichthf. Mantuvieron que allí

70 Véase E.-R. Huber, Deutsche Verfassungsgeschichte, vol. I, op. cit., p. 620 y 621.

71 Véase E.-R. Huber, Deutsche Verfassungsgeschichte, vol. III, op. cit., p. 792.

72 Véase E.-R. Huber, «Bundesexekution und Bundesintervention...», op. cit., p. 1.

73 Véase al respecto P. Schilling, op. cit., p. 78. También a favor de dicha posición R. Von MoHL, op. cit., p. 272 y ss. Contrario a dicha posición M. VON SEYdL, op. cit., p. 38.

74 G. ANschüTz, op. cit., p. 378. 
donde existe un órgano jurisdiccional encargado de enjuiciar la adecuación de la labor de los Länder a la Constitución, la Reichs-exekution del art. 48,1 de la Constitución de 1919 solo podía concebirse como ejecución de la decisión judicial del Staatsgerichtshof ${ }^{75}$. Y así, se mantuvo que el Presidente del Reich podía incluso derogar las leyes de los Länder, incluso del propio Reich, en el caso de que hubiese declarado su inconstitucionalidad aquel órgano jurisdiccional ${ }^{76}$. Sin embargo, la posibilidad de que en ejercicio del poder de coerción pudieran derogarse, en concreto, leyes del Reich fue refutada ampliamente por la doctrina ${ }^{77}$. Esta tesis favorable a un modelo de ejecución dependiente fue también fundamentada desde la teoría del Estado descentralizado.

En la literatura se defendió la tesis de que frente al modelo de la confederación, vinculado a procedimientos (más difusos) de constatación de la infracción normativa, propios del derecho internacional, en un modelo de Estado federal como el reconocido en la Constitución de Weimar, constituye una garantía del mismo que el juicio acerca de la infracción de las normas que lo organizan se encuentre centralizado y sometido a requisitos de objetividad propios de los tribunales de justicia ${ }^{78}$. Por ello, en un Estado federal un poder de coerción como el que se reconocía en el art. 48,1 solo podría materializarse en una ejecución de las decisiones judiciales; construcción teórica que la literatura quería ver reflejada en el propio art. 19 del texto constitucional, que afirmaba: «el Presidente del Reich ejecuta la decisión del Staatsgerichtshof».

El debate académico que ha sido descrito permite reflejar el tránsito del modelo de ejecución independiente hacia un modelo de ejecución dependiente en el sistema descentralizado como consecuencia 1) de la atribución a los tribunales de justicia de la competencia para enjuiciar las infracciones de la Constitución y 2) de la conversión de un sistema confederal en otro ya federalizado. Estas consideraciones no han encontrado, sin embargo, el debido detenimiento en la doctrina de la BZ y han sido zanjadas, como se ha visto, por el TCF, concibiendo al art. 37,1 LF como un poder alternativo a la jurisdicción constitucional, propio del modelo de la confederación. Con todo, habría de repararse en una ulterior cuestión. El debate académico ha reconocido de forma unánime

75 Véase H. Triepel, Streitigkeiten zwischen Reich und Ländern. Beitrage zur Auslegung des Artikels 19 der Weimarer Reichsverfassung, Wissentschäftliche Buchgesellschaft, Darmstadt (Sonderausgabe), 1965, p. 111 y F. W. Jerusalem, Die Staatsgerichtsbarkeit, JCB Mohr, Tübingen, 1930, p. 175 y ss.

76 Véase H. Triepel, op. ult. cit., p. 111.

77 Véase, entre otros, E. Friesenhahn, «98. Die Staatsgerichtsbarkeit» en R. Thoma y G. AnsCHÜTz, op. cit., p. 545.

78 Véase H. Kelsen, «Die Bundesexekution», op. cit., p. 164, 165, H. Kelsen, «Verfassungs und Verwaltungsgerichtbarkeit im Dienste des Bundestaates nach der neuen österreichischen Verfassung vom 1 Oktober 1920», Zeitschrift für schweizerisches Recht, n. ${ }^{\circ}$ 52, 1923-1924, p. 126-161. Como más adelante se analizará, este autor llegó a plantearse si la participación de diferentes órganos en el procedimiento de la coerción, en particular del Jefe del Estado y de un Bundesrat representativo de los intereses de los miembros del Estado descentralizado podía llegar a garantizar una «cierta imparcialidad» parangonable con la que garantiza el ejercicio de la función jurisdiccional, cfr. H. Kelsen, Die Bundesexekution», op. cit., p. 167 y ss. 
que el art. 37,1 LF reconoce un poder extraordinario y una ultima ratio en favor de la garantía del principio federal del art. 20,1 LF ${ }^{79}$. Siendo esto así, habría que plantearse de qué manera esa última ratio puede ser compatible con la concepción del art. 37,1 LF como un poder alternativo y no subsidiario a la jurisdicción constitucional.

\section{LAS MEDIDAS DE COERCIÓN FEDERAL EN GARANTÍA DEL PRINCIPIO DE UNIDAD DEL SISTEMA DESCENTRALIZADO}

\section{La indefinición de las medidas de coerción federal del art. 37,1 LF en el contexto del constitucionalismo histórico}

Quizás uno de los problemas más relevantes a los que se ha enfrentado la teoría de la BZ haya sido definir qué tipo de medidas podría amparar el ejercicio del poder de coerción frente a los Estados federados. El art. 37,1 LF, de manera harto genérica, establece que el Gobierno de la Federación, con la autorización del Bundesrat, "podrá adoptar las medidas necesarias para obligar al Land al cumplimiento de sus obligaciones a través de la coerción federal». Esta indefinición de las medidas de coerción en la LF ha seguido también la tradición de la RE en los textos constitucionales históricos que, con carácter general, también renunciaron a definir las medidas del poder de coerción en el sistema descentralizado. Una indefinición que ha generado en el debate académico importantes controversias doctrinales.

El art. 19 de la Constitución de 1871, de forma similar al vigente art. 37,1 LF, ya establecía que cuando los miembros del Bund no cumpliesen con las obligaciones federales previstas en la Constitución «podrán ser contenidos a través de la ejecución», sin alusión alguna a las medidas que podría amparar. También esa indeterminación de los medios de coerción en el sistema descentralizado se apreció en el art. 48,1 de la Constitución de 1919, a pesar de que en su enunciado se previese que el incumplimiento de las obligaciones por los Länder podría incluso «ser contenido con ayuda de la fuerza armada». Los comentaristas de la Constitución de Weimar acabarían reconociendo de forma unánime que el recurso a la fuerza armada era solo uno de los mecanismos coactivos posibles y no excluía otros no previstos expresamente en el art. 48,1 CW $\mathrm{CW}^{80}$

Para mantener esto, fue frecuente recurrir al argumento a maiori ad minus, que había ejercido en la literatura un decisivo protagonismo en la interpretación del poder de coerción durante la vigencia de la Constitución de $1871^{81}$. En su

79 Véase, entre muchos otros, H. Bauer, «Artikel 37», op. cit., marg. 12 y M. Gubelt, op. cit., p. 1.

80 Véase al respecto E.-R. Huber, Bundesverfassungsgeschichte, vol. VI, op. cit., p. 741 ss., F. SHIRVANI, op. cit., p. 102, 103.

81 Véase H. Triepel, «Die Reichsaufsicht...», op. cit., p. 679. 
esencia, tal argumento doctrinal reconocía que quien puede lo más, puede lo menos, algo que sirvió para reconocer que la consustancial identificación entre la coerción y la fuerza armada propia de sus orígenes — que seguía siendo asumida naturalmente por parte del debate académico- ${ }^{82}$ no podía excluir otros institutos coactivos menos intensos ${ }^{83}$. En estos mismos términos, también durante la vigencia de la Constitución de 1919 se señaló que la expresa previsión de la fuerza armada en el art. 48,1 obedecía solo a la pretensión constitucional de definir el máximo grado de coerción posible frente a los Länder y no excluía otros mecanismos menos coercitivos frente a ellos ${ }^{84}$.

La labor del debate académico desarrollado al amparo de estos documentos constitucionales se centró entonces en tratar de definir cuáles podrían ser esos otros mecanismos coercitivos. Y lo cierto es que, en vez de ser deducidos a partir de una concreta teoría de la Constitución y del sistema descentralizado - lo que se intentó realizar desde escasas posiciones ${ }^{85}$ de forma mayoritaria se siguió recurriendo a soluciones propias de documentos constitucionales históricos. En aras de definir cuáles podrían ser los medios de coerción, el debate de la RE recurrió con gran frecuencia al art. 19 de la Constitución de la Confederación del Norte de 1867. Tal disposición, que había aludido por primera vez en el constitucionalismo histórico a los mecanismos de coerción, establecía que: «la Reichsexekution: a) es acordada y dirigida en asuntos militares, en caso de peligro inminente, por el comandante en jefe del ejército, b) en el resto de casos, es decidida por el Bundesrat y ejecutada por aquél. La ejecución puede extenderse a la sequestratio del Land y su poder de gobierno».

A partir de dicha disposición, la sequestratio del poder del Land fue asumida en el debate académico, junto al tradicional uso de la fuerza armada —ubicada en los orígenes de la RE-, como un mecanismo coercitivo clásico en el sistema descentralizado $^{86}$. A estos se unieron otro tipo de institutos, como la impartición de instrucciones, el nombramiento de comisarios o la deposición de autoridades, cuya relación con aquellos principales mecanismos coactivos se analizará más adelante $^{87}$. Lo cierto es que, con la salvedad de la fuerza armada - mecanismo coercitivo que estuvo vigente en la historia del sistema descentralizado hasta la Constitución de 1919—, la literatura actual ha aceptado para la interpretación del art. $37 \mathrm{LF}$, con algunos matices, las conclusiones presentadas por el debate de la RE. Seguidamente se estudiará en qué términos.

82 Sobre estas posiciones véase G. Jellinek, op. cit., p. 295 y 296, G. MEYER, op. cit., p. 644, M. V. SEYDL, op. cit., p. 137 y ss.

83 Véase ejemplificativamente en la doctrina A. HänEL, op. cit., p. 449-450.

84 Véase G. AnschüTz, op. cit., p. 379.

85 Véase respectivamente H. TriePEL, «Die Reichsaufsicht...», op. cit., p. 677 y ss., H. KelsEN, «Die Bundesexekution...», op. cit., p. 160.

86 Véase A. Hänel, op. cit., p. 452, P. ZÖRn, Das deutsche Staatsrecht, vol I, F. Guttentag Verlagsbuchhandlung, Berlin, 1895 , p. 140.

87 Véase L. V. Rönne, op. cit., p. 72, H. Triepel, «Die Reichsaufsicht...», op. cit., p. 682 y 683. 


\section{La indefinición constitucional de las medidas de coerción federal y el principio de proporcionalidad}

El debate académico ha atribuido a la indefinición de los mecanismos de coerción federal en el vigente art. 37 LF una doble función. De un lado, permitir que puedan llegar a adoptarse todos los medios fácticos y jurídicos, en tanto la Constitución expresamente no los excluya, destinados a garantizar el cumplimiento de las obligaciones que han sido infringidas por los Estados federados. De otro, reconocer un cierto margen de flexibilidad a la Federación para decidir ad casum sobre tales mecanismos, no quedando vinculada por los medios coactivos que hubiesen sido empleados anteriormente para supuestos, incluso, similares ${ }^{88}$.

El art. 37,1 LF, sin embargo, sí ha introducido en su enunciado una novedad respecto de los principales documentos constitucionales históricos, al aludir a que las medidas que legitima el ejercicio del poder de coerción han de ser necesarias para garantizar el cumplimiento de las obligaciones infringidas, una exigencia recogida en el Acta Final de Viena de 1820. De cualquier forma, hay que reconocer que, a pesar del silencio de los textos constitucionales posteriores, la literatura siempre ha acabado por reconocer el requisito de la necesidad como límite a las medidas amparables por el poder de coerción en el sistema descentralizado $^{89}$. Necesidad que ha sido vinculada específicamente en el seno de la LF con el principio de proporcionalidad.

En efecto, ha sido un parecer común en la doctrina entender plasmado en el art. 37,1 LF un principio de proporcionalidad que se materializaría en tres exigencias: a) la idoneidad de las medidas a adoptar por parte de la Federación, en el sentido de que han de ser adecuadas para solventar la infracción de las obligaciones federales por los Estados, b) la necesidad, expresamente plasmada en su enunciado, y que exigiría a la Federación adoptar las medidas menos lesivas para conseguir dicha finalidad y c) la proporcionalidad en sentido estricto, que impondría a la Federación no causar más daño que aquel que se trata de solventar ${ }^{90}$. Sin embargo, desde algún sector doctrinal minoritario se ha llegado a poner en tela de juicio que el principio de proporcionalidad pueda ser considerado un límite a la aplicación del poder de coerción del art. 37,1 LF.

Se ha tratado de defender que el principio de proporcionalidad solo cabe ser aplicado al ámbito de los derechos fundamentales y que los límites al ejercicio del

88 Véase H. H. KLEIN, op. cit., marg. 82.

89 Para la Constitución Imperial de 1871, cfr. H. TrIePEL, «Die Reichsaufsicht...», op. cit., p. 679, A. HäNEL, op. cit., p. 452. En lo que se refiere a la Constitución de Weimar de 1919, véase F. GIESE, Verfassung des deutschen Reiches vom 11. August 1919. Taschenausgabe für Studium und Praxis, ed. Betriebswirtschaftlicher, Wiesbaden, 1925, p. 165.

90 Véase T. Maunz, op. cit., marg. 55, W. ErbGuth, op. cit., marg. 11, M. Gubelt, op.cit., marg. 15, K. STERN, op. cit., p. 717. 
poder de coerción federal solo podrían derivar del principio de lealtad federal ${ }^{91}$. En apoyo de esta tesis se ha esgrimido una cierta jurisprudencia del TCF vertida en la BVerfGE 81, 310: "Junto a la obligación de lealtad federal no existen otros principios de los que puedan derivarse límites para el ejercicio competencial en las $[. .$.$] concretas relaciones Federación-Estados miembros. Los límites derivados$ del principio de Estado de derecho para las intervenciones del Estado en la esfera de libertad de los individuos no es aplicable a las relaciones competenciales Federación-Estados miembros. Esto vale especialmente para el principio de proporcionalidad, al que le corresponde una función defensiva de los derechos individuales y del ámbito de las libertades (cfr. BVerfGE 79, 311 [341]). Las ideas vinculadas con ello contenidas en las categorías de esfera de libertad e intervención no pueden ser aplicadas ni específicamente sobre un determinado ámbito material de una relación de concurrencia entre la Federación y el Estado ni, más en general, a una limitación del ejercicio de competencias».

Lo cierto es que esta construcción doctrinal, aunque minoritaria, permitiría, sin embargo, dotar a la coerción federal un sentido teórico vinculado directamente al principio de lealtad federal, a la que siempre se ha encontrado unido en la historia del sistema territorialmente descentralizado alemán. Si la coerción, como se ha visto, se ha concebido como un mecanismo al servicio del cumplimiento del principio de lealtad al sistema descentralizado, definiendo su supuesto de hecho ${ }^{92}$, podría tener sentido también interpretar a partir de aquél también el contenido y los límites del poder de coerción. En estos términos parece haberse expresado el TCF, como se acaba de exponer.

\section{Los mecanismos de coerción indirecta. La impartición de instrucciones y las medidas de presión financiera}

Como se puso de manifiesto al comienzo de estas páginas, la denominada coerción indirecta engloba las medidas adoptadas por el Estado central frente a las entidades descentralizadas mediante las que se pretende forzar el cumplimiento (por parte de éstas) de las obligaciones federales que han sido infringidas. Históricamente fue la ocupación del territorio por parte del ejército la más intensa medida de coerción indirecta que podía adoptar el Estado central sobre el resto de miembros del sistema descentralizado ${ }^{93}$. Como se ha señalado, la coerción psíquica que genera la ocupación militar del territorio y la subsiguiente amenaza de la guerra tenía como propósito forzar el cumplimiento de las obliga-

91 Véase H. BAuer, «Artikel 37», op. cit., marg. 12, Die Bundestreue, op. cit., p. 242.

92 Véase para la Constitución de 1871, donde la literatura trabó una relación entre coerción, lealtad y secesión, H. Triepel, Die Reichsaufsicht..., op. cit., p. 676 y 677. Véase para la Constitución de Weimar, G. ANschüTZ, op. cit., p. 378.

93 Véase A. Hänel, op. cit., p. 449-450, P. SCHILling, op. cit., p. 70 ss. y G. MeYer, op. cit., p. 644. 
ciones por parte de los territorios ${ }^{94}$. «La denegación de la obediencia puede ser obligada en caso necesario con la aplicación de la fuerza militar» ${ }^{95}$.

El binomio ocupación del territorio (coerción indirecta) — recurso a la guerra (coerción directa) fue característico del modelo de coerción de la confederación del siglo $\mathrm{XIX}^{96}$ y del todo compatible con los mecanismos coactivos reconocidos por el derecho internacional, sobre el que se construyó tal modelo de descentralización territorial ${ }^{97}$. A pesar de la paulatina introducción de elementos federalizantes en el modelo territorial — lo que propició que la doctrina desarrollara de forma paralela otro tipo de mecanismos de coerción llamados a ejercer su función— -98 , lo cierto es que la RE nunca pudo desvincularse del todo de la fuerza armada como mecanismo coactivo en el sistema descentralizado. Éste estaría vigente hasta la Constitución de Weimar de $1919^{99}$.

La actual teoría de la BZ ha negado unánimemente que la ocupación militar del territorio y el posterior uso de la fuerza armada puedan considerarse mecanismos coercitivos admitidos por el art. 37,1 LF ${ }^{100}$. En la vigente LF, han sustituido a la ocupación militar del territorio como clásico instituto de coerción indirecta otros que, con mayor o menor intensidad, ejercen también la función de forzar el cumplimiento de las obligaciones infringidas por las entidades descentralizadas ${ }^{101}$. El primero de los mecanismos de coerción indirecta admitidos en el seno de la LF ha sido la impartición de instrucciones dirigidas a los órganos superiores

94 Véase M. V. Seydu, op. cit., p. 137, H. Kelsen, Allgemeine Staatslehre, ed. Max Gehlen, Berlin, 1966, p. 211 y s. Algún sector de la doctrina de la RE ha denominado esta coerción como militar. Véase P. SCHILLING, op. cit., p. 72, 75 y ss.

95 Véase L. Von RönNe, op. cit., p. 72.

96 Véase G. JellineK, op. cit., p. 295 y 296.

97 Véase H. Kelsen, «Die Bundesexekution...», op. cit., p. 160, p. 248 y s.

98 Cfr. A. HäNel, op. cit., p. 450 y ss. y H. TRIEPEL, «Die Reichsaufsicht...», op. cit., p. 680 y ss. Entre estos autores, sin embargo, existen diferencias a la hora de fundamentar la existencia de este otro tipo de mecanismos de coerción en el seno de la Constitución de 1871, donde aún parte de la doctrina identificaba coerción con el uso de la fuerza armada. Y así, para Hänel, la sequestratio del poder del Land, lo que se materializó en el uso de medidas de sustitución, cabía identificarlo implícitamente en el propio art. 19 de la Constitución, recurriendo, como se puso de manifiesto con anterioridad, a la sequestratio que había sido reconocida expresamente en el art. 19 de la Constitución de la Confederación del Norte de 1849, véase A. HäNEL, op. cit., p. 452. Para Triepel, sin embargo, en el art. 19 de la Constitución de 1871 solo se encontraría la coerción militar. La sequestratio del poder del Land y las medidas de sustitución que ampararía se deduciría del argumento de que el Reich no tiene solo las competencias que la Constitución le reconoce sino otros medios que sirven al mismo fin (teoría a maiori ad minus), véase op. cit., p. 678.

99 La doctrina, sin embargo, trató de diferenciar la guerra, como mecanismo coactivo propio de la confederación, con la intervención armada prevista en el art. 48,1. Ya en la Constitución de 1871, véase M. VoN SEYDL, op. cit., p. 137. Durante la vigencia de la Constitución de Weimar, véase G. ANsCHüTz, op. cit., p. 676 y F. Giese, op. cit., p. 165.

100 Véase W. ErbGuth, op.cit., marg. 13, M. Gubelt, op. cit., p. 14, 22, F. Shirvani, op. cit., p. 102, 120.

101 Además, a diferencia del anterior, la coerción sobre los Länder no se produce por la amenaza al recurso a la guerra, sino por la posibilidad de proceder directamente por la Federación a un cumplimiento sustitutivo de las obligaciones, que abarca un conjunto de medidas de carácter normativo e institucional (la sequestratio). La sustitución de la guerra por este otro tipo de medidas ha sido el resultado de la cristalización del Estado federal. 
de los Länder, institutos coercitivos que ya fueron admitidos en la doctrina en el siglo $\mathrm{XIX}^{102}$.

La impartición de instrucciones tiene como función señalar cuáles son obligaciones que han sido infringidas y cómo proceder a su complimiento, dando la posibilidad al propio Land a que proceda «voluntariamente» al mismo ${ }^{103}$. El gobierno de la federación puede llevar a cabo esta función directamente o a través de comisarios designados a tal efecto, una figura que también puede considerarse clásica de la teoría de la $\mathrm{RE}^{104}$. La doctrina ha señalado que las instrucciones, como mecanismos de coerción indirecta, no pueden identificarse con las que se prevén en el art. 37,2 LF, en el que se dispone: «para la ejecución de las medidas federales coactivas, el Gobierno Federal o su representante tiene el derecho de impartir instrucciones a todos los Estados y a sus autoridades». Las instrucciones a las que se refiere el art. 37,2 LF se conciben, más bien, como medidas complementarias destinadas a ejecutar los mecanismos de coerción directa, como se verá más adelante.

Las instrucciones, como mecanismos de coerción indirecta del art. 37,1 LF, ejercen la misma función que las previstas en los arts. 84 y 85 LF en el marco del procedimiento de inspección reconocido a la Federación (Bundesaufsicht) para el supuesto de ejecución de las leyes federales por parte de los Länder. Ya sea como competencia propia de éstos (art. 84) o por delegación de la Federación (art. 85). En estos casos, si la Federación aprecia deficiencias en la ejecución, puede impartir instrucciones $(84,5$ y 85,3 LF) para garantizar el adecuado cumplimiento de las leyes de la Federación. La doctrina ha señalado, sin embargo, que las instrucciones que cabe encuadrar en el art. 37,1 LF como mecanismos de coerción indirecta no se limitan, sin embargo, a los supuestos de los arts. 84 y $85 \mathrm{LF}$, sino que poseen alcance general, pudiendo señalar y proponer la corrección de cualquier clase de incumplimiento de las obligaciones federales de los Länder ${ }^{105}$.

En la teoría de la BZ quizás represente mayor interés el segundo de los mecanismos que cabe encuadrar en la denominada coerción indirecta: la posibilidad de que la Federación pueda forzar el cumplimiento de las obligaciones que han sido infringidas por parte de los Estados federados denegando ciertas prestaciones debidas a ellos. Es en este plano donde encuentran cobertura las medidas de presión financiera — que ya fueron reconocidas durante la vigencia de la Constitución de Weimar de 1919- ${ }^{106}$ como la retención de partidas

102 Véase H. Triepel, «Die Reichsaufsicht...», op. cit., p. 683 y L. V. RöNNE, op. cit., p. 72.

103 Véase H. H. KLEIN, op. cit., marg. 84.

104 Véase L. VON RÖNNE, op. cit., p. 72: El Reich puede «nombrar y enviar comisarios y dotarles de instrucciones, así como poder ser comunicadas todas las órdenes e instrucciones a las autoridades de los Länder a través de los comisarios del Reich, con el fin de provocar el cumplimiento de la obligación federal, también especialmente instrucciones a las autoridades administrativas...»

105 Véase T. Maunz, op. cit., marg. 5, M. Gubelt, op. cit., marg. 2 y H. Bauer, «Artikel 37», op. cit., marg. 12.

106 Véase G. AnschüTz, op. cit., p. 379 y ss. 
presupuestarias a las que se refiere concretamente el art. 104 a) y b) $\operatorname{LF}^{107}$. A primera vista pudiera suscitar ciertas dudas la posibilidad de incluir estas medidas de presión entre los mecanismos de coerción federal del art. 37,1 LF, si se entendiera que tales medidas se encuentran entre las facultades ordinarias de las que dispone la Federación.

Sin embargo, es aquí donde la particular concepción de las relaciones en el Estado federal alemán presenta perfiles propios. El TCF ha afirmado que del principio de lealtad, que rige, como se ha visto, las relaciones entre la Federación y los Länder, se deriva que ninguno de los miembros del Estado federal puede alegar el incumplimiento de las obligaciones por alguno de ellos para infringir un deber propio (BVerfGE. 8, $122(140))^{108}$. Por tanto, un simple incumplimiento de las obligaciones de los Estados federados, que no satisfaga el supuesto de hecho del art. 37,1 LF, no puede autorizar a la Federación a no cumplir las obligaciones financieras que se prevén en el art. 104 LF. Es, en consecuencia, la infracción a la que se refiere el art. 37,1 LF, idónea para poder poner en peligro el funcionamiento del principio de unidad y el mecanismo extraordinario previsto en tal disposición como último recurso, la que puede legitimar el incumplimiento de las obligaciones por parte del Estado central. De ahí que las medidas de presión financiera solo quepan en el contexto de aplicación del art. 37 LF.

\section{Los mecanismos de coerción federal directa. La sequestratio del poder del Land}

El empleo, sin éxito, de los aludidos mecanismos de coerción indirecta, legitima el empleo de los mecanismos de coerción directa por parte de la Federación ${ }^{109}$. La sequestratio del poder del Land ha sustituido en la vigente LF al empleo de la fuerza armada de la confederación como último mecanismo coercitivo. Como se había afirmado en la doctrina de la RE: «La ejecución se caracteriza por una actuación con la fuerza militar contra el Estado correspondiente» ${ }^{110}$. A través de la sequestratio, la Federación procede a un «secuestro» del poder del Land incumplidor pasando a ejercer las competencias que han sido atribuidas a éstos con la finalidad de garantizar las obligaciones infringidas ${ }^{111}$. En el debate académico se ha admitido una doble vertiente de la sequestratio, una normativa y otra institucional.

107 Véase W. Erbguth, op. cit., marg. 12, M. Gubelt, op. cit., marg. 14, R. SAnnwald, op. cit., marg. 13, H. BAUER, «Artikel 37», op. cit., marg. 13.

108 Véase al respecto en la doctrina H. BAuer, Die Bundestreue, op. cit., p. 337 y ss.

109 También denominada en la teoría de la RE como ejecución civil, por oposición a la militar, que conformaba el núcleo de los mecanismos de coerción indirecta, cfr. P. ScHILling, op. cit., p. 72, 75 y ss.

110 Véase G. Meyer, op. cit., p. 644.

111 Véase R. SANNWALD, op. cit., marg. 13. 
En el plano normativo, se ha admitido mayoritariamente que la Federación, en aplicación del art. 37,1 LF, puede ejercer las competencias legislativas, reglamentarias y ejecutivas de los Länder, una consecuencia que ya fue admitida por la doctrina durante la vigencia de las Constituciones de 1871 y de $1919^{112}$. En caso de acordarse estas medidas de sustitución normativa, la doctrina ha admitido que pueden ser adoptadas por el propio gobierno de la Federación o por un tercero designado por él: un comisario con poder general o especial, por un órgano del propio Land o incluso de otro Estado federado ${ }^{113}$. También se ha admitido que la sequestratio puede ser total o parcial del poder del Land, asumiendo la Federación todas o parte de las competencias atribuidas a aquél ${ }^{114}$.

Idénticamente, ha habido acuerdo en el momento en fijar los límites a las competencias de los Länder que pueden ser secuestradas en aplicación del art. 37,1 LF. Se ha admitido que el poder de coerción no puede autorizar la sequestratio del poder constituyente propio de los sujetos descentralizados ${ }^{115}$, a pesar de que durante la época de la confederación del siglo XIX se llegó a autorizar la derogación de parte de sus Constituciones ${ }^{116}$. Tampoco cabe en la vigente LF, siguiendo aquí la tradición de la RE, la sequestratio del poder judicial de los Länder, por la garantía de independencia consagrada en los arts. 20,3 y 97,1 LF ${ }^{117}$. Tampoco la suspensión del derecho de voto en el Bundesrat, al ser también «expresión directa de su estatalidad ${ }^{118}$. Idénticamente, se ha admitido que la sequestratio del poder normativo no puede ser definitiva, que conlleve una liquidación del Land, por lo previsto en el art. 79,3 LF, que declara intangible la división del territorio federal en Länder, y por el art. $29 \mathrm{LF}$, que somete la reorganización del territorio federal a un procedimiento específico. Por ello, solo cabe una sequestratio de carácter temporal $^{119}$.

En lo que se refiere al contenido de la sequestratio normativa del poder del Land, ha existido acuerdo en la doctrina al considerar que aquélla se identifica con un poder normativo de sustitución de las omisiones de los Estados. En efecto, la mayoría de los comentarios a la LF han aludido expresamente a una «actuación sustitutiva de las omisiones por órganos del Bund o de un tercero», en el marco de una «asunción leal y temporal del poder legislativo y ejecutivo» ${ }^{120}$. Lo cierto es que esta cuestión presenta algún matiz respecto a la RE. En ésta, la sequestratio

112 Véase respectivamente A. HÄNEL, op. cit., p. 450 y G. ANSCHÜTZ, op. cit., p. 377.

113 Véase W. ERbGuTh, op. cit., marg. 12.

114 Véase H. H. KLEIN, op. cit., marg. 86.

115 Véase H. H. KLEIN, op. cit., marg. 98.

116 Véase E.-R. Huber, Deutsche Verfassungsgeschichte, vol. I, op. cit., p. 636.

117 Véase W. ERbGuth, op. cit., marg. 13, R. SANnwald, op. cit., marg. 16

118 Véase R. SAnNwald, op. cit., marg. 16, M. Gubelt, op. cit., marg. 14, 22, W. ERbGuth, op. cit., marg. 13 .

119 Véase W. ERbGuth, op. cit., marg. 13, K. STERn, op. cit., p. 717.

120 Véase H. BAuer, «Artikel 37», op. cit., marg. 13, M. GüBELt, op. cit., marg. 13, R. SANNWALD, 13, H. H. KLEIN, op. cit., marg. 85 
no solo fue considerada tradicionalmente como poder normador destinado a suplir omisiones de los sujetos descentralizados ${ }^{121}$, sino también llamado a derogar normas que incumpliesen las obligaciones federales. Y así, se afirmó que en aplicación de la RE, el Reich podía llegar a derogar leyes de los Länder ${ }^{122}$. Esta concepción de la sequestratio como poder derogador tuvo pleno sentido en la tradición de la RE, en la que ésta, como se tuvo la ocasión de señalar anteriormente, tuvo como función suplir la ausencia de un órgano jurisdiccional competente para enjuiciar las infracciones de la Constitución y de expulsar del ordenamiento los actos contrarios a ella ${ }^{123}$.

Sin embargo, hoy día, esta función, en un Estado federal, se ha trasladado a un tribunal constitucional llamado a ejercer como «legislador negativo» ${ }^{124}$, lo que acaba por convertir a la coerción federal en un poder de sustitución de omisiones de los Länder, como ha señalado la doctrina de la BZ. Sin embargo, en este sentido, convendría reparar en una cuestión vinculada con las relaciones que el propio TCF ha articulado entre la jurisdicción constitucional y el poder de coerción. Como se tuvo la ocasión de apuntar con anterioridad, ante el incumplimiento de las obligaciones federales por parte de los Länder, el TCF ha permitido al Gobierno del Estado central acudir al propio TCF o activar directamente el poder de coerción del art. 37,1 LF. Es decir, se permite que el TCF no ejerza previamente su función como legislador negativo. En esta concepción, probablemente se compadezca mejor con el art. 37,1 LF admitir un poder de coerción también derogatorio — como el vigente en la tradición histórica- en los casos en los que el Gobierno decida no acudir al TCF y opte directamente por la vía reconocida en el art. 37,1 LF.

La teoría de la coerción en el sistema territorialmente descentralizado, bajo la categoría de la sequestratio, no solo ha amparado la asunción de los poderes normativos de las entidades descentralizadas, sino también competencias en el plano institucional. De ello ha sido buena muestra la intervención acordada, durante la vigencia de la Constitución de Weimar, de los Länder de Turingia y Sachsen en 1920. Puesta tradicionalmente como ejemplo en la doctrina de una sequestratio en el ámbito orgánico-institucional, el Presidente del Reich nombró a un comisario con la facultad de deponer de sus puestos a los miembros de los gobiernos y a las autoridades de dichos Länder y de confiar a otras personas la dirección de los asuntos públicos, y de la de asumir el poder del gobierno y autorizarle a convocar nuevas elecciones al Landtag. Esta facultad para el cese de órganos ha sido, en realidad, una nota característica de

121 Véase H. Triepel, «Die Reichsaufsicht...», op. cit., p. 682.

122 Véase A. HäNEL, op. cit. p. 450. p. 446.

123 Véase E.-R. Huber, Deutsche Verfassungsgeschichte, vol. I., op. cit., p. 620 y 621, A. HäNEL, op. cit.,

124 Véase H. Kelsen, «Der Hüter der Verfassung» en H. Klekatsky, R. Marcic y H. Schambeck (edits.), Die Wiener Rechtstheoretiste Schule, Band II, Europa Verlag, Wien, 1968, p. 1873. 
la RE desde su surgimiento mismo en el sistema descentralizado en el siglo XIX hasta la entrada en vigor de la $\mathrm{LF}^{125}$.

El debate académico de la RE, a la hora de definir el alcance prácticamente ilimitado de este tipo de medidas — que también se ha llegado a señalar en el caso de los poderes de sustitución normativa-, ha remarcado que se han encontrado predeterminadas en buena medida por la posición de superioridad atribuida al Reich frente los Bundestaate/Länder en el sistema territorialmente descentralizado $^{126}$. En realidad, esa ha sido una de las notas características sobre las que se ha construido la teoría de la RE, que proyectó sus efectos hasta la vigencia de la Constitución de Weimar de $1919^{127}$. Posiblemente haya sido en este concreto aspecto en el que la teoría de la BZ más se aparta de la RE, en el contexto de un modelo de Estado federal basado en la igualdad entre la Federación y los Estados federados, como ha señalado el TCF en la BVerfGE. 6, $361^{128}$.

La doctrina actual ha descartado de forma prácticamente unánime que el poder de coerción del art. 37,1 LF pueda abarcar lo que se ha denominado una sequestratio en sentido amplio, que pudiera amparar la disolución del Parlamento o el cese del Gobierno del Land o de cualquiera de sus autoridades ${ }^{129}$. Cosa distinta es que, como se ha señalado, la Federación pueda nombrar un comisario que sustituya a autoridades de los Länder en el ejercicio de sus competencias ${ }^{130}$. Algún autor ha defendido que solo podría procederse excepcionalmente a disolver

125 Véase sobre las facultades reconocidas por el art. XXXI del Acta Final de Viena de 1820, E.-R. Huber, Deutsche Verfassungsgeschichte seit 1789, vol. I, op. cit., p. 637. En la Constitución de 1871 también se reconoció como medida de coerción el cese de autoridades, véase H. TRIEPEL, «Die Reichsaufsicht», op. cit., p. 683 .

126 Véase P. LABAND, op. cit., p. 93 y ss., A. HäNEL, op.cit., p. 452, W. SCHMITT, op. cit., p. 290.

127 Véase entre muchos otros, F. GIESE, op. cit., p. 164.

128 Con anterioridad se ha tenido la ocasión de señalar cómo la doctrina, siguiendo el parecer del TCF, negó la teoría de los tres miembros del Estado federal para interpretar el modelo de sistema descentralizado plasmado en la LF. Sin embargo, si algo se le debe a esa teoría es haber tratado de justificar teóricamente por qué en un Estado federal que parte de la igualdad de sus miembros, algo que ha reconocido el TCF, sigue siendo posible admitir una suerte de sequestratio del poder de los Länder. La teoría de los tres miembros del Estado federal caracterizó como función del Estado total en el sistema descentralizado aquella que, sin someterse al reparto horizontal de las competencias, impone deberes y obligaciones dirigidos a todos sus miembros. Esa es la función que desempeña ordinariamente un tribunal constitucional en el Estado federal. Sin embargo, esta teoría también reconoció que una función del Estado total puede llegar a ejercerla un poder de coerción que autorice a órganos de la Federación a no sujetarse al reparto de las competencias y ejercer competencias de los Länder. Ello resulta posible — en un modelo de Estado basado en la posición de igualdad entre la Federación y los Länder - cuando en la decisión sobre el ejercicio del poder de coerción participan todos los intereses presentes en el sistema descentralizado. Por ello, la decisión resultante puede imponerse frente a todos sus miembros, es decir, constituye una decisión del Estado total. Eso es lo que, como se verá más adelante, sucede en la vigente LF, en la que en el procedimiento de aplicación de la coerción participa, por un lado, el Gobierno de la Federación, en representación de los intereses del Estado central y, por otro, el Bundesrat, representando los intereses de las entidades descentralizadas. Véase sobre esta construcción teórica, H. KELSEN, «Die Bundesexekution...,» op. cit., p. 130 y ss.

129 Véase T. Maunz, op. cit., marg. 52, W. Erbguth, op. cit., marg. 13, H. Bauer, «Artikel 37», op. cit., marg. 13, H. SCHÄFER, op. cit., p. 45, R. SANWDWALd, op. cit., marg. 14, M. Gubelt, op. cit., marg. 14. 130 Véase H. H. KLein, op. cit., marg. 86. 
aquellos órganos (el gobierno y el parlamento) cuando la infracción vulnerase los principios electorales del art. 28,1,2 LF: «en los Estados, distritos y municipios el pueblo ha de tener una representación procedente de votaciones generales, directas, libres, iguales y secretas» ${ }^{131}$.

Dos cuestiones han sido objeto de discusión en el debate académico. La primera, la relativa a la posibilidad de envío de fuerzas de policía del Bund, del propio Land incumplidor o incluso de terceros. No ha habido acuerdo al respecto ${ }^{132}$. Tampoco en lo que se refiere a los costes del ejercicio de la coerción sobre el Land incumplidor. La literatura se divide entre los que entienden que ha de ser el Land quien corra a cargo de los costes, dado que el Bund ejerce funciones propias de aquéllos $^{133}$, y los que consideran que ha de ser el Bund el que debe de sufragarlos ${ }^{134}$.

\section{LOS ÓRGANOS INTERVINIENTES EN EL PROCEDIMIENTO DE COERCIÓN FEDERAL}

\section{La iniciativa de la coerción por el Gobierno de la Federación}

El art. 37,1 LF atribuye al Gobierno de la Federación la decisión sobre la procedencia de aplicar el poder de coerción federal frente a los Estados. La atribución al Gobierno de la iniciativa sobre la procedencia de su aplicación implica, a sensu contrario, que la misma está vedada a otros órganos, incluso aunque sean llamados a participar en diferentes fases del procedimiento. En primer lugar, se excluye a los sujetos que forman parte del propio Gobierno, pero no se identifican con éste como órgano colegiado. En concreto, al canciller o a los ministros que, como sucediera con la tradición de la $\mathrm{RE}^{135}$, pueden erigirse en comisarios designados por el propio Gobierno en orden a la ejecución de las medidas aprobadas mediante el procedimiento previsto en el art. 37,1 LF ${ }^{136}$. En segundo lugar, también se excluye al Bundesrat, cuya intervención en el procedimiento previsto en el art. 37,1 LF se limita a la aprobación o no de la iniciativa adoptada por el gobierno.

Como se tuvo la ocasión de señalar, la decisión del Gobierno de la Federación no requiere una decisión previa del TCF, que haya constatado jurisdiccionalmente del supuesto de hecho del art. 37,1 LF, aunque desde alguna posición se haya reclamado su intervención como políticamente recomendable ${ }^{137}$. Aunque el

131 Véase R. SANNwaLd, op. cit., marg. 14.

132 Véase posiciones contrapuestas en W. Erbguth, op. cit., marg. 13 y M. Gubelt, op. cit., marg. 14.

133 Véase R. SANNwald, op. cit., marg. 14.

134 Véase W. Erbguth, op. cit., marg. 20, M. Gubelt, op. cit., marg. 20.

135 Véase L. Von RönNe, op. cit. p. 72

136 Véase R. SANNWALD, op. cit., marg. 11.

137 Véase W. ERbGuth, op. cit., marg. 5. 
supuesto del art. 37,1 LF encierra un juicio jurídico: constatar si los Estados federados han incumplido la Constitución o las leyes federales, el poder de coerción está dotado de una función política: decidir qué concretas infracciones puede tolerar la unidad del sistema descentralizado ${ }^{138}$. La doctrina ha reconocido que la decisión atribuida al Gobierno por el art. 37,1 LF le confiere un amplio margen de discrecionalidad, si bien, sometido a las exigencias del principio de proporcionalidad ${ }^{139}$. Dicho margen de discrecionalidad podría permitir que similares infracciones puedan justificar en unos casos y no en otros, en función del contexto, la aplicación del poder de coerción ${ }^{140}$.

Esta regla general que reconoce al Gobierno un margen de apreciación propio y autónomo para decidir sobre la procedencia de aplicar el poder del art. 37,1 LF ha encontrado, sin embargo, en el debate académico dos excepciones. En primer lugar, se ha apuntado que el margen de discrecionalidad «se reduce a cero» en el supuesto de que se produzca una infracción de los art. 28,1 y 2 LF, que alude a los principios fundamentales que ha de respetar el orden constitucional de los Estados $^{141}$. En segundo lugar, aunque se haya apuntado que, con carácter general, la aplicación de la coerción no se subordina a la decisión previa de ningún órgano, sí se requeriría la previa decisión del Bundesrat en el supuesto del art. 84,4 LF ${ }^{142}$. La citada disposición, dedicada a la «ejecución de las leyes federales como competencia propia de los Länder» atribuye a la Federación un poder de inspección (Bundesaufsicht) sobre los mismos (art. 84,3 LF). Pues bien, en el caso de que los Länder no hubiesen subsanado las deficiencias señaladas por el Gobierno, el Bundesrat ha de decidir si se ha vulnerado el derecho de la Federación. Este sería el caso en el que la decisión del Gobierno de la Federación de aplicar el art. 37,1 LF requeriría una previa decisión del Bundesrat.

Con las salvedades expuestas, la facultad discrecional reconocida al Gobierno no solo le autoriza a decidir «si» procede aplicar la coerción, sino «cómo», es decir, cuáles han de ser las medidas necesarias para garantizar el principio federal. El Gobierno aquí se halla sometido, como se ha señalado con anterioridad, al principio de proporcionalidad, que le exige, ante todo, optar primero por los mecanismos de coerción indirecta, ejerciendo el menor grado de coacción posible sobre el Land infractor y su consiguiente menoscabo de su autonomía. Solo ante el desfallecimiento de tales mecanismos coactivos, podría la Federación proceder a la sequestratio del Land y al consiguiente ejercicio de las funciones atribuidas constitucionalmente al mismo. El principio de proporcionalidad es aplicable también horizontalmente, al elenco de las medidas que abarcan respectivamente los mecanismos de coerción indirecta y directa.

138 Véase H. Bauer, «Artikel 37», op. cit., marg. 12, M. Gubelt, op. cit., marg. 1.

139 Véase W. ERbGUTH, op. cit., marg. 11.

140 Véase H. H. KLEIN, op. cit., marg. 82.

141 Véase W. ErbGuth, op. cit., marg. 14, K. Stern, op. cit, p. 716.

142 Véase W. ERbGuth, op. cit., marg. 15. 


\section{La aprobación de la coerción por el Bundesrat}

La procedencia de aplicar el poder de coerción y las medidas propuestas por el Gobierno para garantizar la eficacia del principio federal, requieren de la aprobación definitiva del Bundesrat. Un juicio que, como el del Gobierno, posee una naturaleza política autónoma ${ }^{143}$. De ahí que se haya apuntado que el juicio del Gobierno no es vinculante para el Bundesrat y éste puede denegar, con arreglo a motivos de oportunidad, la aplicación del art. 37,1 $\mathrm{LF}^{144}$. La intervención del Bundesrat en el procedimiento del art. 37,1 LF tiene un doble sentido señalado por la doctrina: a) dotar de una legitimación federal a la decisión, toda vez que es llamado al procedimiento del art. 37,1 LF, como verdadera cámara de representación territorial, para la defensa de los intereses de las entidades descentralizadas y b) la defensa frente a decisiones precipitadas ${ }^{145}$.

La doctrina ha apuntado que el consentimiento prestado por el Bundesrat no impone automáticamente la aplicación del poder de coerción en el Estado federal. Tras su autorización, el Gobierno debe de constatar si los presupuestos para ejercer la coerción persisten, en cuyo caso ha de procederse a la aplicación del poder del art. 37,1 LF. Como se puede ver, se vuelve a reconocer al Gobierno, en la fase final, un nuevo poder autónomo de decisión, si bien éste no puede amparar una desviación de las medidas aprobadas por el Bundesrat ${ }^{146}$. También ha habido acuerdo en la doctrina en señalar que el Bundesrat, a pesar del silencio de la LF, puede revocar, a iniciativa propia, su consentimiento en cualquier momento, siguiendo aquí lo que se disponía en el art. 48,3 de la Constitución de 1919, que permitía al Bundestag dejar sin efecto la aplicación del poder de coerción ${ }^{147}$. Además, también ha existido acuerdo mayoritario en atribuir a dicho poder revocatorio del Bundestag efectos ex nunc, no afectando a las medidas que hubieran sido ejecutadas ${ }^{148}$. Otras posiciones doctrinales, sin embargo, han señalado que la decisión revocatoria tendría efectos ex tunc, retrotrayendo sus efectos al momento mismo de su aprobación ${ }^{149}$.

143 Véase R. SANNwald, op. cit., marg. 18.

144 Véase T. Maunz, op. cit., marg. 40, W. ErbGuth, op. cit., marg. 18, M. Gubelt, op. cit., marg. 18, G. A. ZINN, op. cit., p. 303.

145 Véase W. Erbguth, op. cit., marg. 18, T. Maunz, op. cit., marg. 37 y ss., M. Gubelt, op. cit., marg. 17, R. SANNWALD, op. cit., marg. 18, H. BAUER, op. cit., marg. 11.

146 Véase H. BAuER, «Artikel 37», op. cit., marg. 12.

147 Véase W. ERbGuth, op. cit., marg. 18, H. BAuer, «Artikel 37», op. cit., marg. 11. Hay que señalar, sin embargo, que en la Constitución de Weimar de 1919, la decisión sobre si aplicar el poder de coerción y las medidas llamadas a garantizar el cumplimiento de las obligaciones federales por parte de los Länder descansaba en exclusividad en el Presidente del Reich, sin que ningún otro órgano tuviese que proceder a su aprobación. Su art. 48,3 establecía solo el deber irrenunciable del Presidente de ponerlo en conocimiento del Reichstag, además de atribuirle a éste el poder de «dejar sin efecto» la aplicación de la coerción.

148 Véase R. SANNWALD, op. cit., marg. 18.

149 Véase H. BAuer, «Artikel 37», op. cit., marg. 11. 


\section{CONCLUSIONES}

El reconocimiento de un poder de coerción a órganos del Estado central para garantizar el cumplimiento de las obligaciones de los Bundestaate/Länder ha sido una característica del sistema territorialmente descentralizado alemán. Surgido durante la confederación del XIX, bajo la denominación Reichsexekution, ha continuado siendo plasmada en los textos constitucionales posteriores, cristalizando en la categoría de la Bundeszwang en el art. 37 de la vigente LF. Ante la ausencia de aplicación práctica desde la entrada en vigor de la LF y de los casi inexistentes pronunciamientos del TCF, la literatura ha asumido para la interpretación del art. 37 LF prácticamente los resultados presentados por la doctrina de la Reichsexekution, que definió los perfiles del poder de coerción a partir de un modelo de Constitución y de descentralización territorial bien distintos a los reconocidos en la LF.

El poder de coerción del art. $37 \mathrm{LF}$ — no sin controversias doctrinales que afectan a diferentes elementos del mismo - se concibe como una respuesta a la infracción de las obligaciones federales por parte de los Länder. Las obligaciones federales son las que a) relacionan entre sí a los miembros del Estado federal, b) se encuentran plasmadas en la Constitución o en las leyes de la Federación y c) se vinculan directamente con el principio de unidad del Estado federal. La infracción de las obligaciones federales ha producirse por los órganos superiores de los Länder: los gobiernos y los parlamentos. La infracción ha de ser real y efectiva y puede derivar de acciones y de omisiones y venir ocasionada por un comportamiento doloso o culposo.

El contenido del poder de coerción de la Federación consiste, en primer lugar, en adoptar medidas para forzar el cumplimiento de las obligaciones federales por los propios Länder y, en el caso de no producirse tal cumplimiento, en segundo lugar, permitir a la Federación asumir las competencias propias de los Länder y sustituirlos en el cumplimiento de las obligaciones federales (sequestratio). Estos dos momentos coactivos, ya reflejados por la doctrina de la Reichsexekution, se expresan respectivamente a través de los conceptos de coerción indirecta y coerción directa. La aplicación de estas medidas coercitivas está sometida a las exigencias del principio de proporcionalidad y no requieren de una decisión jurisdiccional previa del TCF que haya acreditado la infracción de las obligaciones federales por parte de los Länder.

Entre las medidas de coerción indirecta en el art. 37 LF se han aceptado las que ya había presentado la doctrina de la Reichsexekution: las instrucciones, el envío de comisarios y las medidas de presión financiera. Las medidas de coerción directa se identifican con un poder normativo de sustitución de las omisiones de los órganos superiores de los Länder, a través de la asunción de su competencia legislativa, reglamentaria y ejecutiva (sequestratio normativa). La doctrina actual ha excluido de manera prácticamente unánime las medidas de sequestratio institucional que sí fueron admitidas en la doctrina de la Reichsexekution. Se ha descartado que el poder de 
coerción del art. 37 LF pueda amparar el cese del gobierno y la disolución de los parlamentos de los Länder.

La decisión de aplicar el poder coactivo frente a los Länder y el contenido de las medidas es una decisión discrecional atribuida al Gobierno de la Federación. Sin embargo, para su aplicación definitiva se requiere la aprobación del Bundesrat, que ha de aceptar o rechazar las medidas propuestas por el Gobierno. El Bundesrat puede revocar su autorización en cualquier momento con efectos ex nunc.

$$
* * *
$$

TITLE: The Federal coercion in the Basic Law for the Federal Republic of Germany. The reception of a traditional category of the german federal system

AвSTRACT: This paper analyses the federal coercion in the Basic Law for the Federal Republic of Germany. The Federal coercion allows the Central State to respond to a breach of the federal obligations by the federated states. The literature has not developed a theory of the federal coercion for the german Constitution. The function and the content of the federal coercion in the current german Constitution has been imported of the category of the federal execution, arisen from the XIX german confederation system and based on a different concept of Constitution and decentralized State.

Resumen: Este trabajo analiza la categoría de la coerción federal en la Ley Fundamental alemana. La coerción federal atribuye al Estado central la facultad de responder frente a la infracción de las obligaciones federales por parte de los Estados federados. La doctrina apenas ha construido una teoría de la coacción federal vinculada a la vigente Ley Fundamental, sino que ha asumido, con carácter general, los resultados de la ejecución federal. Una categoría que encuentra su origen en la época de la confederación alemana del siglo XIX y en un concepto de Constitución y de sistema descentralizado distintos a los asumidos en la vigente Constitución.

KEY WORDS: federal coercion, Federal execution, Principle of unity, Constitutional theory.

Palabras clave: coerción federal, Ejecución federal, Principio de unidad, Teoría de la Constitución.

FECHA DE RECEPCIÓN: 15.12.2018

FECHA DE ACEPTACIÓN: 05.02.2019 
